\title{
EKLEKTISISME TASAWUF: METAMORFOSIS SUFISME DAN RELEVANSINYA DENGAN TAREKAT MODERN
}

\author{
Amir Maliki Abitolkha \\ Universitas Islam Negeri Sunan Ampel Surabaya, Indonesia \\ E-mail: amir.abitolkha@gmail.com
}

\begin{abstract}
Among the background of the emergence of Sufism is the Muslim struggle against the contestation and power struggle of the Umayyads in the second century Hijri. The problems of power, politics, and religious conflicts that gave birth to a pragmatic and materialist attitude by some Muslims were then addressed by some ascetics by voicing an ascetic attitude towards such matters. After developing and splitting into several tarekat, the ideological values of Sufism also changed and shifted and even led to the path of the ideology of Sufism. This shift is what this research wants to uncover, considering how important it is to explain the pure ideology of Sufism by presenting historical and contextual studies as a shield for worldly conflicts and power. By using literature research, this article concludes that the style of Sufi teaching that adheres to the eclecticism model has historical roots as a balance between the profane and the secular. The eclectic Sufi style contains three basic principles of Sufi teachings, namely realizing worldly life as an undeniable reality, spiritual practice rituals such as remembrance and relying on sharia. In addition, Sufi teachings with an eclectic style have a strong level of relevance to religious patterns in Indonesia, the pattern of Sunnī madhhab.
\end{abstract}

Keywords: Sufism, Sufi, eclecticism, Neo-sufism, sharia.

\section{Pendahuluan}

Secara historis, pemikiran tasawuf lahir dari ide berkelompok para zāhid (ahli zuhud) di serambi masjid Madinah. ${ }^{1}$ Setelah beradu pengalaman batin dan mengamati konstelasi politik Islam, mereka mengambil langkah untuk beribadah total dan mengembangkan

\footnotetext{
${ }^{1}$ H. A. Rivay Siregar, Tasawuf dari Sufisme Klasike ke Neo-sufisme, Cet. II (Jakarta: Raja
} Grafindo Persada, 2002), 36. 
rohani untuk mengabaikan keindahan duniawi. Pemikiran ahli rāhid ini diterima oleh masyarakat Muslim sebagai jawaban dari berbagai persolan duniawi yang tidak kunjung selesai. Pada abad ketiga Hijriah, pemikran tasawuf berkembang pesat. ${ }^{2}$ Masalah inilah yang disebut dengan fase asketisme (belum disebut sufisme), dimana aktivitas zubud menjadi penyeimbang dari aktivitas keduniaan. Istilah "penyeimbang" disini mendandakan bahwa pemikiran tasawuf mampu meredakan pertarungan ideologi-ideologi radikal dan konflik kekuasaan.

Keberhasilan perkembangan pemikiran tasuwuf pada ilmu pengatahuan Islam mengokohkan tasawuf sebagai cabang ajaran Islam yang terfokus pada aspek kebertuhanan dengan menanggalkan sisi-sisi keduniaan. ${ }^{3}$ Sehingga ideologi asketisme tersebut dipatenkan dengan istilah sufisme, yakni paham ajaran Islam yang memiliki landasan teologis dan disiplin keilmuan berbasis pada rohani melalui metode kashf. Ajaran sufisme berkembang bukan tanpa alasan, karena menurut Mustafa Numsuk ajaran sufi berkembang karena mampu memberikan spirit ketuhanan yang bisa menenangkan jiwa dan rohani, menciptakan kedamaian hati dan melupakan kekejaman duniawi. Melalui ragam latihan batin (riyädah) seperti sifat zubd, wara', tawakekal, dhiker dan sebagainya, diyakini bisa menghapus ragam sifat egois, otoriter, dan angkuh. ${ }^{4}$

Seiring berkembangnya pemikiran sufi pada ordo sufi (tarekat) terutama pasca-lahirnya neo-Sufisme sejak abad keempat belas hingga sekarang pergulatan sufi mulai tercerabut dari induk asalnya. ${ }^{5}$ Akibatnya, aliran-aliran sufi bukan lagi menjadi penyeimbang

2 Abad ketiga Hijriyah merupakan awal pertama kali ilmu tasawuf menjadi sebah ilmu sejajar diantara ilmu-ilmu alam dan agama, diakui satu-satunya ilmu tentang kebatinan yang mengarah pada teologis adalah ilmu tasawuf. Lihat lebih jelas dalam Meutia Farida, "Perkembangan Pemikiran Tasawuf dan Implementasinya di Era Modern", Jurnal Substantia 12, no. 1 (2011), 106-107.

${ }^{3}$ Harun Nasution, Filsafat dan Mistisisme dalam Islam (Jakarta: Bulan Bintang, 1973), 57.

${ }^{4}$ Ahmad bin Abdul Aziz al-Husain dan Abdullah Mustofa Numsuk, Kesesatan Sufi: Tasawuf, Ajaran Budha (Jakarta: Pustaka as-Sunnah, 2001), 6-7.

${ }^{5}$ Ketercerabutan akar keilmuan tasawuf dipengarui oleh beberapa hal; 1) politik kelembagaan, yakni antar tarekat sufi saling bersaing untuk mendapatkan anggota dan pengikuti sehingga tidak jarang mereka mendekati penguasa agar mampu memberikan massa. 2) kekuasaan, dimana pada masa 'Abbāsīyah dan Turki Ustmani, tarekat sufi diperhitungkan sebagai basis masa yang berpengaruh terutama setelah tenggelamnya aliran kalam dan fikih. Lihat Dimyati Sajari, "Keotentikan Ajaran Tasawuf', Dialog 38, no. 2 (2015), 146-147. 
kepentingan duniawi atau bukan juga berdiri diatas kerohanian murni, melainkan berpijak pada pondasi otoritas dan teologi aliran yang mengarah pada fanatisme, konservatisme bahkan sampai pada profanisme. Fanatisme menggambarkan bahwa ilmu tasawuf disandarkan pada figur murshid tarekat tanpa melakukan filter dan kritik. Konservativisme ini mengarah pada model aliran sufi yang mendewakan aliran komunitas, sedangkan profanisme mengilustrasikan ritual agama Islam hanya berlandas pada ukuran kehusukan seraya meniadakan unsur fikih (syariah). ${ }^{6}$

Beberapa kasus seperti pembekuan tarekat Naqshabandiyah di Jawa Tengah karena mengajarkan ajaran menyimpang ${ }^{7}$ adalah bukti bahwa nilai sakral ajaran tasawuf tidak lagi murni. Oleh karena itu, sejatinya terdapat tiga masalah imbas pergeseran tasawuf, yaitu pertama kekeliruan memaknai nilai kesufian pada ritual beragama. Ritual kesufian diartikan dengan makna ukhrawi semata, yakni mengajarkan bahwa keberadaa dunia adalah hal yang tidak penting, fatamorgana, dan tidak bermakna. Sehingga ritunitas kegiatan dunia benar-benar ditanggalkan; kewajiban dan tanggungjawab lainnya pun tidak dilaksanakan. Pemahaman sufi seperti ini banyak terjadi pada tarekattarekat modern, dimana mereka meninggalkan tanggungjawab dengan beritual ke gua-gua selama berbulan-bulan untuk menggapai status anggota tarekat. ${ }^{8}$ Tentu ritual demikian bertentangan dengan ajaran Islam.

Kedua, kekeliruan memaknai hukum dalam ajaran Islam. Sikap fanatis umat Islam untuk menjadi anggota tarekat tertentu terkadang tidak dilandasi dengan pemahaman Islam yang utuh, sehingga cara memaknai hukum Islam dimaknai pada interpretasi sufistik secara total. Seperti dalam memaknai konsep khusü' dalam salat fardu, ị̣tisāb dalam puasa, dan lainnya. Menurut mereka, sekalipun rukun dan syarat ibadah salat terpenuhi, jika tidak khusū' maka salat tersebut ditolak (tidak sah). Pula dengan kewajiban puasa, jika tidak dilandaskan pada rasa ikhlas maka puasa tersebut batal. Cara

${ }^{6}$ Lihat dalam Achmad Mulyadi, "Budaya Egalitarianisme Perempuan Madura dalam Tarekat Naqshabandīyah”, Karsa: Jurnal Sosial dan Budaya Keislaman 23, no. 1 (2015), 6-7.

7 Thahirah Binti Hassan Basri, Faudzinaim bin Badaruddin, dan Abdul Manam bin Mohamad, "Konsep Zikir Darajah dalam Disiplin Ilmu Tarekat", Jurnal Islam dan Masyarakat Kontermporer 8, no. 2 (2014), 117.

8 Alfi Julizun Azwar, "Tasawuf dan al-Qur'ān Tinjauan Dunia Ilmu Pengetahuan dan Praktek Kultural-Religius Ummat”, Intizar 19, no. 2 (2013), 232-234. 
beragama kaum sufi seperti ini, ditemukan pada anggota tarekat yang sebelum mendalami ilmu tasawuf tidak memilliki dasar ilmu agama yang cukup. Sehingga cenderung menanggalkan ilmu syariah secara total dan menggunakan ilmu tarekat untuk mengukur kebenaran beragama. Inilah yang ditakuti oleh Hidayati konsep kesalehan zuhud tanpa dilengkapi dengan dasar-dasar illmu fikih, mengakibatkan manusia terjerembab pada rituak ahirat dan melupakan tanggung jawabnya sebagai khalifah. ${ }^{9}$

Ketiga, fanatisme aliran. Setiap gerakan sufi tentu memiliki guru (murshid) yang dipercaya dan diyakini mampu membimbing ke jalan yang benar dan bisa menyelamatkan dirinya di akhirat nanti. Sehingga apa yang menjadi perintah darinya adalah fatwa yang harus diikuti. Yang menjadi persoalan, sumber beragama tidak lagi menggunakan ajaran Islam yang masyhur seperti al-Qur'ān, al-Hadīth dan Ijmă ulama. Tarekat-tarekat seperti ini banyak ditemuai bahkan menjamur ke penjuru daerah di Indonesia. Tidak jarang terdapat tarekat yang berlindung di balik jubah organisasi tertentu, dengan tujuan tertentu. ${ }^{10}$ Fanatisme aliran dan kemurshidan inilah menjadi problem aliran sufi modern.

Dari ketiga problem sufi diatas, kerangka ideologi sufisme perlu diletakan pada posisinya semula. Salah satu tawaran konsep sufisme dikenal dengan istilah eklektisisme sufi yang mewakili konsep sufi abad kedua hijriah sebagai konsep sufi yang sebenarnya, bukan konsep sufi yang telah mengalami pembaruan ataupun bercampur aduk dengan figuritas dan fanatisme aliran. Eklektisisme sufi mengandung tiga konsep, yakni pertama integralitas doktrinal, yakni memaduka antara teologi spiritual dengan teologi syariah. Pemaduan ini disandarkan para ritual Rasulullah, dimana beliau tidak menanggalkan tanggungjawab duniawi sepenuhnya untuk mendekatkan diri kepada Allah. Satu sisi menjalankan kewajiban mu'ämalah, di sisi lain tetap menjalankan ibadah secara sufi. Kedua, spiritual sosialis. Yakni melakukan ritual sufi dalam bentuk persiapan (zubd, wara', șabr, hilm, dan lain-lain) namun juga mengikuti kegiatan-kegiatan sosial secara terbuka. Terbuka dalam artian, banyak menyambung tali silaturahim,

\footnotetext{
9 Tri Wahyu Hidayati, "Perwujudan Sikap Zuhud dalam Kehidupan”, Millati: Journal of Islamic Studies and Humanties 1, no. 2 (2016), 92-93.

${ }_{10} \mathrm{Kemal} \mathrm{A.} \mathrm{Riza,} \mathrm{"Ascetism} \mathrm{in} \mathrm{Islam} \mathrm{and} \mathrm{Christianity:} \mathrm{with} \mathrm{Reference} \mathrm{to} \mathrm{Abu}$ Hamid al-Ghazali and Francis of Assisi”, Toesofia: Indonesian Journal of Islamic Mysticism 1, no. 1 (2012), 2303.
} 
berpartisipasi dan komunikasi dengan masyarakat. Ketiga, teologisdoktrinal. Yakni menerima pemaknaan agama orang lain secara ekslusif untuk membenahi pemahaman sufi yang selama ini dipahami. Artinya, cara bersufi tidak selalu disikapi dan dipraktikkan secara fanatis atau dogmatis. ${ }^{11}$

Oleh karena itu, rekonstruksi pemikiran sufistik perlu diungkap secara literalis untuk mengembalikan pemahaman tasawuf yang sebenarnya dengan melakukan kajian historis secara mendalam mengaitkan dengan tarekat-tarekat yang berkembang di era kontemporer. Konsep eklektisisme sufi berupaya mena-warkan reinterpretasi ideologi sufi modern dengan cara mengembalikan pemahaman sufi ke ranah induk ataupun akar keilmuan sufistik. Penelitian ini sekaligus menjawab problem tasawuf modern yang telah keluar jalur sufistik. Konsep pemurnian yang diusung oleh konsep eklektisisme sufi tidak sama dengan konsep puritan, konsep eklektisisme menekankan pada pengembalian asal ideologi karena memang hal demikiran yang moderat dan seimbang. Bukan malah semakin meruncing masalah dan menghilangkan nilai esensial sufistik.

\section{Asal Mula Doktrin Tasawuf}

Sebelum ilmu tasawuf dikokohkan sebagai gerakan sufisme, pemikiran zuhud menjadi embrio bibit lahirnya sufisme. Asketisme para zăhid pada abad ke 1 Hijriah atau tujuh Masehi yang berpandangan bahwa umat Islam butuh ajaran model kebertuhanan terpusat, dimana umat Islam tidak hanya memikirkan tentang kepentingan duniawi beserta biruk pikuk-nya, melainkan ajaran penyeimbang spiritual kebertuhanan dan keduniaan. ${ }^{12}$ Menjadikan dunia dan akhirat bersifat paralel maupun berjalan beriringan. Ajaran tasawuf bukan ajaran terpisah dengan ajaran Islam saat itu, melainkan hanya penyeimbang saja. Karena Islam pada abad pertama sejak rasulullah wafat telah dirundung persolan politik dan kekuasaan yang berorientasi pada keduniaan semata. ${ }^{13}$ Sementara persoalan akhirat, tidak begitu didalami. Oleh karena itu, ajaran Islam membutuhkan orientesi akhirat sebagai penyeimbang.

11 Usman, "Urban Sufisme: Jalan Menemukan Kembali Humaintas yang Hilang Akibat Modernitas", Jurnal Tasawnf 1, no. 1 (2012), 66-67.

12 Reynold A. Nicholson, "Sufism" dalam James Hastings, Encyclopaedia of Religion and Etics (London: Charles Scribe's, t.th.), 10-11.

13 Syamsul Rijal, "Kritik Ibnu Taimiyah terhadap Tarekat", Jurnal Penelitian dan Pemikiran Keislaman 2, no.1 (2015), 59-60. 
Pada abad kedua hijriah, ajaran asketisme para zähid didaulat menjadi ajaran sufisme. Gerakan sufisme dikokohkan oleh kelompok asketis, bukan tanpa alasan, melainkan respon protes dari kolompok orang-orang saleh terhadap kekuasaan bani Umayyah. ${ }^{14}$ Pergolakan tragis perebutan kekuasaan dan konflik internal dalam tubuh Islam dianggap umat Islam sedang mengalami krisis religius yang berbanding terbalik dengan prinsip keislaman yang diajarkan oleh Nabi Muhammad beserta para khalifah. Sebagai bentuk protes, gerakan sufisme membawa arah baru perabadan Islam melalui ritualritual sufi di banyak negara, aktivitas spiritual dan kembali kepada Allah. ${ }^{15}$ Gerakan ini mampu menghipnotis mayoritas umat Islam berkelompok mendalami ajaran sufisme.

Secara tidak langsung, ajaran sufisme bukan sekadar doktrin semata, melainkan juga gerakan penyeimbang (bukan pembaruan ataupun purifikasi) terhadap kondisi beragama, bersosial dan bernegara yang terjadi pada umat Islam. Para zähid yang tergolong sebagai sufisme merasa kebatilan dan kedzaliman terjadi dimanadimana, sekalipun tidak berbentuk kejahatan atau kekerasan, melainkan berupa "terfokus pada orientasi dunia dan sibuk dengan urusan-urusan dunia", dalam ajaran sufisme hal demikian juga termasuk kedzaliman. ${ }^{16}$ Oleh karena itu, sebagai bentuk gerakan sufisme menarik diri dari pergumulan dan hiruk-pikuk politik kekuasaan dengan cara mengumpulkan umat Muslim yang saleh untuk bersikap agamis, sambil juga melancarkan kritik. Kritik berbentuk tindakan-tindakan moral dan menolak kekerasan, bukan dalam bentuk peperangan.

Dengan demikian, gerakan sufisme mengarah pada dua pola pergerakan; gerakan doktinal dan gerakan moral spiritual. Gerakan doktrinal berupa ritual-ritual zikir, kontemplasi, membaca kalimatkalimat tayyibah, menjauhkan diri dari maksiat, dan sebagainya sebagai upaya mendekatkan diri kepada Allah. Sementara gerakan moral spiritual diarahkan pada tindakan kritik secara berjemaah kepada penguasa Muslim saat itu. Kelompok yang tergabung dalam gerakan

14 Nurcholish Madjid, Islam Doktrin dan Peradaban: Sebuah Telaab Kritis tentang Maslahah Keimanan, Kemanusiaan dan Kemodernan (Jakarta: Yayasan Wakaf Paramadina, 1992), 257.

15 Elmansyah al-Haramain, Paradigma Peradaban Islam dalam Tasawuf: Sebuab Pemaparan Awal (Bandung: Mizan, 2014), 141-142.

16 Ali Mas'ud, "Analisis dan Mapping Syariah Versus Tasawuf melalui Pendekatan Historis", Episteme 8, no. 1 (2013), 156-157. 
sufisme adalah para orang-orang saleh yang menyukai kehidupan menyepi, menyendiri, berkhalwat dan beribadat kepada Allah. Mereka kurang begitu tertarik pada selain mendekatkan diri kepada Allah seperti kekuasaan, politik, ekonomi. Tercatat, yang mengetuai gerakan sufisme pertama kali adalah Ḥasan al-Bașrī (w. 110 H.) seorang saleh terkemuka di abad pertama Hijriah. ${ }^{17}$

Pada abad kedua Hijriah, gerakan sufisme bergerak pada bidang teologi dengan menampilkan gerakan anti ritualistik yang menekankan pada signifikansi kesalehan. ${ }^{18}$ Perlawanan gerakan sufisme tidak lagi pada politik kekuasaan dan keduniaan, melainkan pada ranah yang lebih saintifik, yakni ilmu fikih. Abad ke-2 H/8 M dipenuhi dengan kemunculan ilmu serba fikih dan kalam pada peradaban kaum Muslim terutama di kawasan Basrah. ${ }^{19}$ Fenomena ini membawa pengaruh besar bagi perkembangan keilmuan Islam, dimana meletus perbedaan ritual keagamaan yang berujung pada takfiri dan fanatis. Persoalan merebaknya pendekatan serba fikih dan teologi (kalam) menyibukan umat Islam dengan kajian-kajian hadist yang diwarnai perpecahan aliran kaläm seperti Murji'ah, Mu'tazilah, Shī'ah. Kondisi inilah yang memancing gerakan sufisme untuk mene-gakan gerakan anti ritualistik. Pada akhirnya, sufisme memuncukan kesalehan tinggi melalui gerakan zuhud tinggi. Pada gerakan ini, zubud bukan sekadar anti-sosial, melainkan mengarah pada pemaknaan humilitas dimana tingkat kezuhudan seperti melukan masalah keindahan dan kebutuhan fisik seperti makanan dan pakaian. ${ }^{20}$

Bahkan lebih parah dari itu, gerakan sufisme benar-benar berubah arah dari prinsip keseimbangan dunia-akhirat, bergeser ke akhirat murni. Semisal konsep tawakal yang semula berada di jalur etis, akhirnya dimaknai pada posisi sufi tinggi yaitu berkembang menjadi doktrin ekstrem tentang pengingkaran dunia. Dalam hal apapun, umat Islam berserah diri secara total tanpa mengejar dunia,

17 Ubaidillah, "Fitrah dan Potensi Insani daam Ilmu Tasawuf (Perspektif erapi Psikologis dan Bimbingan Konseling)", Jurnal Konseling Religi: Jurnal Bimbingan Konseling Islam 1, no. 1 (2010), 12-15.

18 Lihat dalam Arthur C. Bohart dan Thomas Greening, "Comment: Humanistic Psychology and Positivve Psychology", Journal American Psychologist 56, no. 1 (2001), 4432.

${ }_{19}$ Lihat dalam M. Solihin dan Rosihon Anwar, Ilmu Tasawnf (Bandung: Pustaka Setia, 2011), 10-12.

20 Mahfud Salimi, "Reformasi Tasawuf al-Ghazali dan Relevansinya dengan Pendidian Islam”, Az-Zikr: Jurnal Pendidikan Agama Islam 1, no. 1 (2016), 5-7. 
itu artinya, gerakan sufi dibentuk pada aspek elakukan ritual dzikir dan memasrahkan diri. Dengan kedua konsep sufisme ini (zubud dan tawakkal) ini, bukan semata mematikan kerangka perkembangan ilmu fikih dan ilmu kalam, melainkan juga aktivitas keduniaan manusia. Masa inilah yang disebut dengan sufisme ekstrem, ternyata setelah ditelusuri, pernyataan sufi ekstrem tersebut dikhususkan untuk melawan umat Islam dengan konsep anti-ritual. ${ }^{21}$

Pada fase ke-3 hijriyah, gerakan sufi sudah terbilang masif dan disahkan sebagai disiplin keilmuan Islam. Para zähid merumuskan konsep-konsep baku seperti fanä', ma'rifat, ḩulül dan lain sebagainya. Istilah zubd dan tawakkal mengalami metamorfosis pemaknaan dan implementasinya, sehingga tasawuf menjadi lebih sempurna. Secara wilayah, ajaran tasawuf sudah mapan dan menjadi ciri khas suatu daerah basis pengembangan ilmu tasawuf, yaitu tasawuf ala Khurasān dan tasawuf ala Baghdād. Aliran tasawuf Khurasān, pola tasawuf yang berkembang bercorak doktrin tawakkal yakni memasrahkan seluruh urusan kepada Allah yang cenderung panteistik, spekulatif, berbeda pada pemaknaan tawakkal pada asal katanya dan mengabaikan ketentuan syariah Islam. Seperti beberapa sufi termasyhur yaitu alḤallāj (w.309 H) dengan doktrin ḅulül-nya yang terkenal anà al-ḥaq. Seperti pula al-Bistāāī (w.201 H) yang terkenal dengan doktrin fan $\bar{a}^{, 22}$ Pola tasawuf seperti demikian yang banyak diyakini orang sebagai ilmu tasawuf tingkat tinggi, seolah-olah menafikan keberadaan dunia dan secara berlebihan berada pada kekuatan supratural.

Sementara tasawuf ala Baghdäd tetap kokoh dengan prinsip awal ideologi akar (growt ideology) yaitu menekankan kesalehan dan kezuhudan. Secara tegas ajaran tasawuf ini menolak keras asketisme radikal, doktrin fan $\bar{a}^{\prime}$ dan tetap berpegang pada ketentuan-ketentuan syariah islam disamping menjalankan tradisi peribadatan umat Islam pada umumnya. Model tasawuf seperti ini dirintis dan dikembangkan oleh sufi seperti Ḥārith al-Muhāsibīi (w. 234 H) dan muridnya Junayd al-Baghdādī (w. 298 H). ${ }^{23}$ Dari Junayd inilah berkembang model

${ }^{21}$ Alba, Tasawuf dan Tarekat (Bandung: PT Remaja Rosdakarya, 2012), 73-74.

22 Mohammad Fahmi Abdul Hamid, Ishak Hj Suliaman, dan Mohd Farhan Md Ariffin, "The Concept of Zuhud Based on Fiqh Hadìth", Jurnal Intelek 11, no. 1 (2016), 24-30.

${ }^{23}$ Lihat A.J. Arberry, "Sufism: an Account of the Mystics of Islam" dalam Aceng Kosasih, "The Tradition for Spiritual Learning (Tariqat) Through a Sequence of Holy Phrases (Tijaniyah): the Case of Darussalam Boarding School", Asian Social Science 11, no. 2 (2015), 71. 
tasawuf tersebut sampai menjadi besar. Model tasawuf Junayd merupakan kepanjangan dari aliran tasawuf pada mula lahir, karena memang model seperti inilah yang dimaksud dengan keseimbangan antara doktrin dengan kerohanian. Tidak condong pada salah satu pihak, atau memihak ke bagian yang lain.

Ketegangan antara dua model ajaran tasawuf tersebut memuncak pada abad keempat Hijriah atau abad ke 10 Masehi. Alhasil, aliran tasawuf ala Baghdadd lebih bisa diterima oleh masyarakat ketimbang aliran tasawuf Khurasān. Keberhasilan demikian disebabkan oleh dukungan ulama-ulama ortodoks seprti al-Sarrāj (w. $377 \mathrm{H}$ ) dan al-Kalābadhī (w. 390 H) serta banyak ulama-ulama ortodoks lain yang berpengaruh. Pada abad kelima, tasawuf model Baghdäd yang dirintis dan dikembangkan al-Junaid mencapai puncak kejayaanya saat ditekuni oleh Abū Ḥāmid al-Ghazālī (w. 505 H), yang berhasil membawa ilmu tasawuf sebagai basis keilmuan Sunnī. ${ }^{24}$ Dengan kepandaian ilmu fikih dan kalam, al-Ghazālī mampu menelurkan ajaran tasawuf moderat yang bukan hanya merekonstruksi Islam ortodoks, melainkan menjadikan tasawuf integral antara ajaran tasawuf dan syariah Islam.

Fase-fase metamorfosis tasawuf diatas, jelas bahwa ada dua dua ajaran besar yang berkembang sebagai embrio gerakan sufisme. Pertama, corak sufistik atau ajaran tasawuf yang berada di tengah antara ajaran tasawuf dengan ketentuan syariah Islam, dan kedua corak sufistik yang condong pada total pada konsep teologi doktrinal, yakni melupakan atau menafikan urusan dunia dan menggantungkan pada doktrin transendental. Kedua aliran ini sampai saat ini masih samasama hidup dan berkembang sebagai aliran sufi, begitupun di Indonesia. Tinggal bagaimana umat Islam meyakini mana yang dianggap benar dan mana yang diangkap munkar.

\section{Neosufisme: Antara Sosio-Moral dan Ortodoksi}

Ditengah dominasi ajaran tasawuf al-Ghazālì sejak abad ke-4 Hijriyah, namun bibit-bibit tasawuf aliran Khurasān ternyata belum tercerabut sampai ke akar. Munculnya doktrin waḥdat al-wujüd (kesatuan eksistensi) yang dilontarkan Ibn 'Arabi merupakan bentuk perkembangan aliran Khurasān. Waḥdat al-wujūd dimaknai dengan "wujud itu satu; semua yang tambak banyak, sesungguhnya adalah

${ }^{24}$ Ira M. Lapidus, History of Islamic Societies (Cambridge: Cambridge University Press, 1993), 112. 
satu kesatuan; dan semua yang tampak merupakan wujud luar Tuhan". ${ }^{25}$ Namun meskipun aliran ini adalah puncak perkembangan ilmu tasawuf, namun tidak pernah lepas dari hujatan dan kritik dari golongan ortodoks karena bersifat teologi sentral.

Melihat perkembangan puncak tasawuf yang tidak sehaluan dan dianggap berbahaya menyesatkan bagi umat Islam, terutama umat Islam yang bersikap taqlid karena kerendahan dasar ilmu agama, maka ulama ortodoks melakukan pembaruan ajaran tasawuf baru (reformed sufism) yang disebut dengan neosufisme. Dirintis oleh Ibn Taymiyyah (w. $728 \mathrm{H}$ ) bersama muridnya Ibn Qayyim (w. $751 \mathrm{H}$ ), keduanya berikhtiar menciptakan wajah tasawuf baru untuk melunturkan ajaran tasawuf Khurasān atau konsep waḅdat al-wujūd. ${ }^{26}$ Neosufisme mengangkat pembaruan dengan senantiasa berpegang pada al-Qur'ān dan Hadìth yang memusatkan pada rekonstruksi sosio-moral umat Islam tanpa harus menanggalkan kehidupan duniawi yang nyata. Itu artinya, konsep neosufisme mengusung tiga entitas sekaligus; ajaran zubd dan tawakkal, menekankan pada syariah Islam, dan sosio-moral masyarakat Muslim. ${ }^{27}$ Dengan itu, neosufisme melibatkan peran individu dalam masyarakat.

Dengan kata lain, neosufisme menekankan pada moral dan menerapkan metode dhikr dan muräqabah (konsentrasi pada rohani) untuk mendekatkan diri pada Tuhan, namun penekanan tersebut tetap berpegang teguh pada ajaran doktrin syariah. ${ }^{28}$ Dalam perkembangannya, ajaran neosufisme dianggap ajaran pembaruan tasawuf yang sesuai dengan syariah Islam, dan disisi lain pembaruan dilakukan untuk melawan ajaran tasawuf waḥdat al-wujüd yang dianggap reingkarnasi dari tasawuf Khurasān. Perbedaan mencolok antara tasawuf Junayd dengan neosufisme adalah pengembangan pada aspek sosio-moral. Sehingga banyak ulama ortodoks yang menerima neosufisme sebagai terobosan keilmuan sufistik yang relevan pada abad pertengahan.

Bahkan akhir abad pertengahan (abad ke $14 \mathrm{H}$.) gerakan neosufisme benar-benar menguasai ajaran tasawuf dan sepenuhnya diterima oleh umat Islam kalangan sunni. Pasalnya, neosufisme di sunni berikhtiar untuk membersihkan ajaran tasawuf lama yang penuh

\footnotetext{
${ }^{25}$ Reynold A. Nicholson, The Mystics of Islam (London: Kegan Paul, 1966), 3-4.

26 Siregar, Tasawnf, 237-238.

${ }^{27}$ Nicholson, The Mystics of Islam, 5.

${ }^{28}$ Fazlur Rahman, Islam (Chicago: the University of Chicago Press, 1979), 129.
} 
penyimpangan dan menjerumuskan kaum awam ke lembah kesesatan berpikir. Neosufisme dengan pendekatan baru yakni mengawinkan tasawuf kontemplatif-purifikatif dengan syariah Islam sekaligus teologis, menjadi perpaduan integral yang sesuai dengan al-Qur'ān dan Hadith. Gerakan neosufisme tidak bersifat sekuler, apalagi teologis sentral, akan tetapi mengedepankan prinsip moderat dengan menekankan pada tiga aspek penting dalam Islam; ibadah, syariah dan muamalah. Ibadah digambarkan oleh prinsip teologi seprti tawakal dan maqämät, syariah digambarkan oleh keterkaitan nilai pada syariah Islam dan muamalah digambarkan oleh tujuan moral sosial, ${ }^{29}$ sehingga membentuk gugus ilmu tasawuf yang sempurna dan relevan dengan perkembangan ilmu pengetahuan.

Sampai abad modern, jangkauan neosufisme telah sampai ke seluruh kawasan dunia Islam, termasuk Indonesia. Neosufisme berhasil memberikan arah baru duni tasawuf yang elegan dan moderat. Bahkan neosufisme menjadi embrio berkembangnya tasawuf modern yang digagas oleh Buya Hamka yang sangat terkenal. ${ }^{30}$ Sehingga dalam waktu berabad-abad lamanya, neosufisme mampu mengontrol dan mengawal perkembangan tasawuf agar tidak kembali lepas dari akar asalnya. Jikapun mengalami pembaruan, hanya pada aspek-aspek tertentu dan masih berpegang teguh pada akar doktrin tradisionalnya. Maka keberadaan neosufisme secara tidak langsung telah membawa perubahan mendasar untuk menjauhkan tasawuf pada kesesatan. Lambat laun, neosufisme tanpa disadari telah mampu mendamaikan konsep waḥdat al-wujūd-nya Ibn 'Arabī dengan ajaranajaran syariah. ${ }^{31}$

Sampai kemudian berkembang di era kontemporer berbagai macam ajaran tasawuf, namun akar neosufisme tetap berada pada jantung ajaran, yakni sekalipun berkembang di masa-masa selanjutnya, tasawuf tetap berada pada pengawasan syariah Islam dan syariah tetap menjadi bagian integral dari doktrin tasawuf. Maka dengan sendirinya, sejak masuknya syariah Islam ke dalam doktrin tasawuf bisa memperkokoh posisi Islam ortodoks, yang pada generasi tasawuf

\footnotetext{
${ }^{29}$ Nurcholish Madjid, Islam Agama Peradaban: Membangun Makna dan Relevansi Doktrin Islam dalam Sejarah (Jakarta: Paramadina, 2000), 78.

30 R.S. O'Fahey, Enigmatic Saint: Ahmad Ibn Idrisi and the Idrisi Tradition (London: Hurst and Company, 1990), 4.

31 Derek Hoopwood, “A Pattern of Revival Movements in Islam?” dalam Armyn Hasibuan, "Neo-Sufisme, Ragam dan Perkembangannya (Mampukah Membangun Konstruksi Baru)", Hikmah 7, no. 2 (2013), 59-62.
} 
berikutnya ikut andil dalam melakukan rekonstruksi dan reformasi ajaran tasawuf kontemporer yang disebut dengan tarekat-tarekat. Seperti halnya pergulatan sufisme dan neosufisme, ternyata tarekattarekat saat ini juga terkontaminasi oleh ajaran-ajaran di luar syariah sebagai imbas dari keawaman dan ketakpahaman akar historisitas dari ilmu tasawuf. Di bawah ini dijelaskan mengentai lahir dan degradasi ideologi sufistik pada tarekat-tarekat.

\section{Tarekat dan Perubahan Doktrin Tasawuf}

Istilah tarekat dalam literatur kajian sufistik memiliki dua makna yang hanya dapat dimaknai secara akar kesejarahannya. Makna pertama, tarekat diartikan dengan ajaran kerohanian yang memberikan tuntutan spiritual kepada seorang sälik dalam kehidupannya dalam rangka menuju diri ke hakikat Tuhan. Sedangkan makna kedua, bermakna komunitas dimana bergaung sejumlah sufi yang dibimbing oleh seorang murshid (guru spiritual) yang taat pada aturan-aturan khusus dan memiliki rutinitas pertemuan kerohanian secara periodik. ${ }^{32}$ Pada pemaknaan pertama, tarekat menjadi sebuah jalan yang harus ditempuh olelh seseorang melalui proses yang dinamakan abwal dan maqāmät untuk sampai ke tujuan akhir yaitu márifat Allah. Inilah pengertian yang banyak dinukil oleh seorang sufi dalam ilmu tasawuf dimana tasawuf menjadi jalan spiritual yang mesti ditempuh untuk menjadi seorang sälik agar sampai kepada yang Mahah Besar. Sedangkan untuk makna kedua, biasanya lebih bersifat umum, artinya, selain anggota kelompok aliran sufi, juga ada asosiasi lain yang ikut mendapatkan wejangan dari murshid. Macam tarekat inilah yang pada periode ini muncul dengan skala besar yang jumlah pengikutnya sangat mayoritas.

Beberapa tarekat yang muncul dahulu adalah tarekat Qādirīyah di Irak, Baghdad dan paling banyak pengikutnya sampai sekarang, didirikan oleh 'Abd al-Q̄ādir al-Jīlānī (w. 525 H). tarekat Rifāīìah di Bashrah yang didirikan oleh Aḥmad Rifā̄ō (w. $578 \mathrm{H}$ ), tarekat Shādhilīyah di Afrika Utara yang didirikan oleh Abū al-Hasan alShādhilī (w. $656 \mathrm{H}$ ), tarekat Kubrāwìyah di Persia yagn didirikan oleh Ahmad al-Badawī (w. $675 \mathrm{H}$ ), tarekat Naqshabandīyah di Asia Asia Tengah yang didirikan oleh oleh Bahā’ al-Dīn al-Naqshabandī (w. 791

\footnotetext{
32 Muhammad Shodiq, "Eksistensi dan Gerakan Dakwah Tarekat Siddîqîyah di Tengah Masyarakat Urban Surabaya", Teosofi: Jurnal Tasawnf dan Pemikiran Islam 5, no. 2 (2015), 347.
} 
H) dan banyak lagi tarekat-tarekat di dunia yang aktif dan memiliki massa yang banyak, bahkan jumlah keseluruhan tarekat di dunia sebanyak 177 ordo. ${ }^{33}$ Meskipun varian tarekat berbeda-beda, namun secara doktrinal tidak ada perbedaan mendasar antar satu tarekat dengan tarekat yanglain, kecuali hanya pada aspek ritualnya saja, seperti cara membaca zikir dan amalan-amalan lain. Semisal tarekat Rifā‘̄ìah menginginkan zikir dengan suara keras sedangkan Naqshabandīyah, zikir dengan nada yang sedang. ${ }^{34}$ Namun secara tujuan yang ingin dicapai, pada prinsipnya sama-sama ingin meningkatkan kualitaas moral-spiritual dalam ajaran agama Islam untuk mencapai Yang Mahahaq.

Johns (1987) menyebutkan bahwa penyebaran tarekat di dunia tidak menimbulkan konflik, karena disebarkan secara penerimaan batin. Sekalipun lahirnya tarekat di wilayah-wilayah tertentu, namun penyebarannya ke penjuru-penjuru daerah lain seperti tarekat Qādirīyah yang didirikan di Baghdad menyebar ke Mesir, Magrib, India, Yaman, Afrika Barat sampai ke Asia Tenggara. Begitu pula dengan tarekat Naqshabandīyah, sekalipun lahir di Bukhara namun memayoritas di India yang kemudian menyebar ke Asia Tengah, Cina, Timur Tengah sampai ke Indonesia. Begitu juga dengan tarekattarekat yang lain, tidak berhenti di satu wilayah saja. Lanjut Johns, keberhasilan ekspansi tarekat sufi bukan hanya karena daya tarik esoterik bathiniyah, melainkan terjadinya kekecauan dan tumbangnya kekuasaan Islam ke tangan non-Muslim, sehingga mendorong umat Islam untuk memasuki dunia tarekat. Sedangkan disisi psikologi ajaran agama, tarekat menjadi "rumah besar" yang menjadi tempat perlindungan ruhani yang goncang dan mempersilahkan siapa saja untuk memasukinya. Tarekat menjadi semacam "rumah sakit" yang didera bertubi-tubi dengan cekikan kekuasaan dan pegolakan agamaagama. $^{35}$

Masalah autentitas tarekat mulai mengalami degradasi sejak naiknya dinasti Utsmani pada abad kedelapan dan kesembilan Hijriyah. Secara perlahan tarekat berubah menjadi gerakan sufisme popular dengan bercabang-cabang dan membentuk aliran-aliran. Sehingga terjadilah perubahan signifikan terhadap nilai ritual amaliah

\footnotetext{
${ }^{33}$ Nursyam, Perkembangan Kaum Tarekat (Surabaya: LEPKISS, 2004), 56-57.

34 Martin van Bruinessen, Kitab Kuning, Pesantren dan Tarekat (Yogyakarta: Gading Publishing, 2015), 102-104.

35 Ibid., 106.
} 
dan ideologi sufi ke ranah "ideal" dan yang "praksis" serta tarekat dengan kepercayaan "umum" dan "lokal". ${ }^{6}$ Disitulah problem mulai nyala, sesudah abad kedua belas gelombang islamisasi terjadi dimanamana, anehnya gelombang tersebut melalui jalan-jalan tarekat dan tasawuf, sehingga ilmu tasawuf berbaur dengan kepentingankepentingan agama lain serta menjadi api yang membakar ajaran Islam "yang sesungguhnya". Berbaurnya ideologi-ideologi politik dan nonMuslim ke dalam tarekat-tarekat merubah akar keilmuan sufisme menjadi berubah, gelombang seperti ini terjadi di Asia Tengah, Eropa Timur, Mesir sampai ke Indonesia. ${ }^{37}$

Asumsi Trimingham (1979), ada dua faktor yang menyebabkan degradasi tarekat; internal dan eksternal. Faktor internal, erjadi pada ketidakmampuan para guru sufi menyingkap keilmuan baru atas pondasi keilmuan yang telah ditancapkan oleh ulama-ulama sebalumnya. Kejumudan inilah yang menjadi faktor kemunduran, sementara di lain pihak, ilmu-ilmu keislaman terus berkembang. Sementara faktor eksternal, terjadi pada keinginan formalisme pengikut tarekat sehingga menjauhkan diri dari perbincangan substansi asli ajaran sebenarnya. Akibat dua faktor tersebut, tarekat digiring pada ranah kultus dan bependangan mistik seperti tahayul, khurafät, dan bidah, yang sebenarnya bukan kehendak pada guru-guru sufi. ${ }^{38}$ Ajaran sufi seolah hanya mengajarkan tentang hal-hal yang mistik dan takhayyul.

Di saat tarekat berada pada masa kelam, muncul gerakangerakan dari luar tasawuf yang mengatasnamakan ajaran sufi atau bahkan mengatakan cabang dari ajaran sufi yang telah mapan. Gerakan-gerakan ini mengibarkan bendera untuk memurnikan ajaran sufi yang dianggap menyimpang. Ajaran sufi yang telah digagas dan mapan oleh ulama seperti Junayd, Bahā' al-Dīn al-Naqshabandī, Ibn Taymìyah, al-Ghazālī dan semacamnya dianggap usang dan perlu pemurnian yang lebih relevan dengan perkembangan Islam. ${ }^{39}$ Tak ayal, pembaruan tersebut berakibat pada berubahnya doktrin dan

\footnotetext{
36 Akhmad Rizqon Khamami, "Tasawuf Tanpa Tarekat: Pengalaman Turki dan Indonesia", Teosofi: Jurnal Tasawnf dan Pemikiran Islam 6, no. 1 (2016), 3-5.

${ }^{37}$ Khozin, Sufi tanpa Tarekat: Praksis Keberagamaan Muslim Puritan (Malang: Madani, 2013), 78.

38 Anemearie Schimmel, Mystical Dimenssions of Islam dalam Abdelilah Bousria, Sufism and Politics in Morocco: Activism and Dissent (New York: Routledge, 2015),78-79.

39 Mohammad Noupal, "Tarekat Naqsabandiyah di Indonesia Abad 19 dari Ortodoksi ke Politisasi”, Intizar 22, no. 2 (2016), 298-299.
} 
amalan-amalan tarekat lama, sekaligus mengusung ajaran sufi baru yang berupa pengembangan amalan-amalan. Hal inilah yang mengacaukau gerakkan sufisme hingga saat ini.

\section{Merumuskan Tarekat Baru: Eklektisisme Doktrin Tasawuf}

Seperti dipaparkan diatas, degradasi tarekat dan pembaruan doktrin dan amalan-amalan sufi sebagai bentuk pemurnian, memantik rekonsioliasi antara ulama sufi tradisional dengan ulama-ulama ortodoks untuk mengembalikan makna sesungguhnya. Satu-satunya cara adalah melakukan eklektisisme, yaitu mengembalikan keilmuan tasawuf ke dalam pangkuan syariah Islam. Hal ini mirip awal mula berkembangnya gerakan sufisme dan asketisme (aliran ₹āhid), bedanya kalau penyegaran tersebut terbentuk melalui lembaga-lembaga tarekat. Di India, sebagai basis gerakan sufi Naqshabandīyah bercabang menjadi gerakan tarekat al-Mujaddidīyah yang disetiri oleh Aḥmad alSirhindī, sebuah gerakan sufisme yang bertuuan untuk mengembalikan tarekat ke pangkuan syariah. Gerakan tarekat alMujaddidīyah telah berkembang ke luar India. ${ }^{40}$ Pada abad kesembilan belas muncul pula tarekat pengembangan yang dinamakan Naqshabandīyah khalidiyah yang didirikan oleh Mawlānā Khālid, bertujuan sama untuk mengembalikan tarekat ke pangkuan syariah. ${ }^{41}$ Di Indonesia sendiri muncul tarekat Shatarīyah dan Qādirīyah Naqshabandīyah yang dipelopori oleh ulama sufi asal Indonesia bermukim di Makkah yaitu Syaikh Ahmad Khatib al-Sambasi. ${ }^{42}$

Akhirnya pada akhir abad ke-19 gerakan pembaruan tarekat di Indonesia mencapai puncaknya dengan memunculkan tarekat-tarekat baru seperti Tijānīyah, 'Idrīsīyah dan Sanūsìyah, begitu juga di kawasan luar Indonesia seperti Afrika. ${ }^{43}$ Secara dokrin ajarannya, tarekat pembaruan untuk melawan kaum ekstremesme doktrin, maka diambil dari cara neosufisme beranjak namun dengan pola yang lebih lengkap, yaitu mendukung aktifisme duniawi tanpa mengorbankan

\footnotetext{
40 Hamid Algar, "The Naqshbandi Order: A Preliminary Survey of its History and Significance" dalam M. Arif Khoiruddin, "Peran Tasawuf dalam Kehidupan Masyarakat Modern", Tribakti: Jurnal Pemikiran Keislaman 27, no. 1 (2016), 113-115. 41 Yunasril Ali, "Dualisme: Pemikiran Sufistik Ibn Taymiyyah", Kan₹ Philosophia 4, no. 2 (2014), 156-158.

42 Joko Tri Haryanto, "Perkembangan Dakwah Sufistik Perspektif Tasawuf Kontemporer", Addin 8, no. 2 (2014), 270-278.

${ }^{43}$ Lihat dalam Alwi Shihab, Islam Sufistik: Islam Pertama dan Pengarubnya Hingga Kini di Indonesia (Bandung: Mizan, 2001), 4-5.
} 
pemenuhan spiritualnya seraya kembali ke pangkuan syariah Islam. Dengan doktrin seperti ini, mereka berniat untuk menyatukan Islam kembali dan tidak mejadikan tasawuf berpisah dengan al-Qur'ān dan Hadìth sebagai sumber ajaran Islam yang sesungguhnya. Kendati wilayah doktrin dan amalan bertrandensi kepada Tuhan, juga ditunjang oleh ritual zikir dan tawakal namun juga tidak melupakan kehidupan duniawi sebagai kehidupan nyata dan muamalah sosial. Akan tetapi secara ideologi atau sufistik, gerakan-gerakan pembaru ini memiliki tujuan sama dengan ajaran sufi ulama klasik sebelumnya serti Junayd, al-Ghazālī, yakni untuk menyempurnakan jiwa manusia namun bukan pada jalan menyatukan dirinya dengan Tuhan, melainkan menaladani Rasulullah dengan cara muräqabah untuk mencapai kesucian jiwa. ${ }^{44}$

Sampai abad ke-20, gerakan sufisme memiliki banyak ragam varian doktri dan amalan. Dari akar sejarah perkembangan tasawuf, terdapat tiga pola ajaran sufi yang hidup hingga saat ini, yaitu pertama ajaran sufi yang tetap menganggap kehidpan duniawi adalah realitas kehidupan nyata yang tidak dipungkiri karena sifat kemanusiaannya, mendekatkan diri kepada Allah untuk mencapai ma'rifat dan menjadikan syariah sebagai landasan bertasawuf. Pola ajaran sufi seperti ini yang dimaksud dengan eklektisisme doktrin tasawnf. Sekalipun dalam perkembangannya, bermetamorfosis ke dalam skup yang lebih luas, namun tidak sampai mencabut ketiga nilai ajaran (realitas duniawi, ma'rifatullah dan syariah). Semisal dengan menambah kelembagaan sosial, moral dan kultur. Kedua, ajaran sufi yang menafikan kehidupan duniawi dan terfokus pada penyatuan dengan Tuhan dalam setiap tindakan dan perilakunya, sehingga aliran tarekat ini adalah pengejewantahan dari teori waḥdat al-wujüd Ibn 'Arabī. Ketiga, ajaran sufi yang mengusung konsep ma'rifatullah dengan cara mendekatkan diri kepada Allah dan tidak melupakan sisi keduniaan secara total, namun tidak menggunkan syariah sebagai bagian dari doktrin amaliyah sehari-hari. ${ }^{45}$

Dari ketiga pola tersebut, secara cerdas semestinya cabang aliran tarekat sufi tidak melapaskan diri dari ajaran prinsip utama

\footnotetext{
${ }^{44}$ R.J.I. Ter Laan, "Sanusi Revivalism as Part of the Fundamentalist Tradition in Islam," dalam Nicola A. Ziaderh, Sanusiah: a Study of a Revivalist Movement in Islam (Leiden: E.J. Brill, 1983), 140.

45 Sulaiman al-Kumayi, "Gerakan Pembaruan Tasawuf di Indonesia”, Jurnal Theologia 24, no. 2 (2013), 335-336.
} 
terbentuknya doktrin ajaran tasawuf, seperti yang dilekatkan oleh Junayd al-Baghdādī, Hạarith al-Muḥāsibī, al-Ghazālī dan pengikutpengikutnya yang sealiran. Prinsip utama ajaran tasawuf adalah eklektisisme dengan menggabungkan tiga prinsip dasar yaitu menyadari pentingnya realitas kehidupan duniawi, amaliyah-amaliyah dbikr, tawakkal, wara', sabr, tawbah, dan semacamnya yang menjadi tangga mencapai ma'rifat kepada Allah dan prinsip terakhir adalah menekankan pada syariah. Ketiga unsur inilah oleh Bruinessen diumpakan seperti bangunan teologi syariah, dengan menjadikan realitas kehidupan duniawi sebagai jalan untuk mencapai ma'rifatullah, bukan sebagai penghalang. Untuk mencapai ma'rifatullah atau mendekatkan diri kepada Tuhan dilalui dengan doktri yang disebut dengan amalan-amalan seperti zikir dan tuntutan hidup seperti tawakal, sabar, dan tobat. ${ }^{46}$ Namun seluruh rangkaian ajaran tasawuf tersebut disesuaikan dengan syariah sebagai hukum Allah sebagai jalan mencapai hakikat.

Eklektisisme adalah paham tasawuf yang mengkritik ajaran wahdat al-wujüd. Kritik ditekankan pada cara mencapai márifat Tuhan. Jika waḥdat al-wujüd murni menggunaan kashf sebagai penggalian ajaran-ajaran dan keinginan Tuhan sedangkan eklektisisme menjadikan syariah dan amalan-amalan sufi sebagai konsep integral untuk mencapai ma'rifat. Inilah perbedaan prinsipil yang berimbas pada pola pandang umat Islam dalam bertasawuf. Konsep waḥdat al-wujüd memiliki konsekuensi kesesatan yang tinggi jika gagal dipahami olah umat Islam yang memiliki dasar ilmu agama yang terbatas. Sedangkan konsep eklektisisme memiliki tujuan yang sama dengan waḥdat al-wujūd namun dengan metode ajaran yang mudah dipahami. Menurut Azyumardi Azra konsep tasawuf yang diusung Junayd dan al-Ghazālī serta para pengikutnya adalah konsep yang mengarah pada pemahaman moderat dalam beragama, sehingga kemungkinan berkonflik sangat sedikit dan lebih dekat pada pencapaian ma'rifat. Sedangkan konsep ajaran tasawuf klasik (wahdat al-wujūd) mengarah pada pemahaman agama yang fundamental, puritan sampai ke radikalistik. $^{47}$

\footnotetext{
46 Martin van Bruinessen, Tarekat Naqshabandiyah di Indonesia (Bandung: Mizan, 1998), 67.

${ }^{47}$ Lihat dalam artikel Mahrus As'ad, "Pengaruh Nesufisme terhadap Perkembangan Tasawuf dan Tarekat Baru”, Miqat XXXVI, no. 1 (2012), 44-46.
} 
Semisal, menganai diterimanya amaliah salat fardu, menurut pola ajaran tasawuf yang meniadakan syariah, maka ukuran sahtidaknya (diterima-tidaknya oleh Allah) semata diukur dari kekhusuan hati (qalb). Pengukuran ini dianalogikan seperti konsep tawakal, ikhlas dan sabar, yang juga merupakan produk hati. Sebaliknya, jika salat dilaksanakan tanpa rasa khusū ${ }^{-}$di hati sekalipun telah sesuai dengan aturan syariah Islam, maka dianggap sia-sia (tidak sah). Inilah yang menjadi problem, terutama bagi umat Islam yang dasar ilmu agamanya masih lemah, khawatir terjerumus ke dalam kesesehatan atau bahkan radikalisme. Berbeda dengan ajaran eklektisisme tasawuf berpendangan bahwa ukuran sah-tidaknya ritual pelaksanaan salat bergantung pada terpenuhinya rukun dan syarat sesuai syariah Islam (al-Qur'ān dan Hadīth, Ijmā' ulama fikih), sekalipun kekhusukan tidak didapat. Konsep khusü dapat dicapai saat umat Islam telah mampu melakukan riyädah salat yang diulang-ulang, sampai mencapai khusū. Oleh karena itu, khusǘ dalam salat dicapai ketika manusia telah sampai pada ranah ma'rifat sebagai tujuan. ${ }^{48}$ Ajaran ini yang relevan dipraktikkan dalam kehidupan tasawuf dari sejak lahir sampai hari ini.

\section{Eklektisisme Tasawuf dan Relevansinya di Era Modern}

Metamorfosis yang begitu mencolok tentang tarekat di era modern adalah melibatkan diri dalam agenda-agenda politik. Penghujung abad ke-19 dan awal abad ke-20 tarekat-tarekat seperti tarekat Naqshabandiyah, tarekat Sanusiyah dan tarekat Qadiriyah, manasbihkan dirinya untuk tidak hanya bergerak dalam bidang-bidang sufi semata, namun bertanggung- jawab untuk menyelematkan umat Islam dari cengkraman ajaran-ajaran Islam radikal, wahabi dan gerakan menyimpang lainnya. Tarekat-tarekat tersebut melindungi identitas religio-cultural umat Islam menghadapi penguasa-penguasa zalim dan kafir. ${ }^{49}$ Bahkan untuk mensukseskan tujuan tersebut, mereka meneriakan jïhäd melawan musuh-musuh Islam. Seruan jïhäd tersebut tentu sebagai gambaran dari ajaran sufi eklektisisme, karena konsep jihäd hanya ada pada syariah. Seperti Tarekat Sanusiyah di bawah pimpinan Sayyid al-Mahdi mengangkat senjata melawan kaum

48 Louis Ma'luf, al-Munjid fì al-Lughah wa al-A'lām dalam Munirul Abidin, "Pandangan Neo Sufisme Nurcholis Madjid (Studi tentang Dialektika antara Tasawuf Klasik dan Tasawuf Modern di Indonesia)", Ulul Albab 9, no. 1 (2008), 2223.

${ }^{49}$ Lihat Muh. Said, "Metodologi Penafsiran Sufistik: Perspektif al-Ghazali", Jurnal Diskursis Islam 2, no. 1 (2014), 145-146. 
fanatis agama Kristen di Italia, Tarekat Naqshabandīyah Khalidiyah mempelopori perlawinan di dunia Barat terhadap agresi kolonialis Eropa serta Tarekat Qādirīyah Naqshabandīyah di Indonesia yang melawan kaum penjajah Belanda. ${ }^{50}$ Perlawanan-perlawanan tarekat tersebut, tentu sebagai wujud dari penegakan syariah Allah agar senantiasa ajaran Islam tidak punah.

Perlu digarisbawahi bahwa perlawanan kaum tarekat, baik di Indonesia maupun internasional, ditujukan kepada dua entitas; penguasan non-Muslim dan paham sekuler. Ini menandakan bahwa ruh eklektisisme sufi menjadi ideologi panutan untuk perkembangan tasawuf modern. Sekularisme juga problem ajaran Islam karena menafikan kehidupan ukhrawi, dan cenderung total pada kehidupan duniawi. Tentu ajaran ini berbanding terbalik dengan ajaran tasawuf yang tidak membuat gap antara duniawi dengan ukhrawi. Sebagai bentuk pengokohan syariah, perlu dilawan ajaran-ajaran yang menyimpang dari prinsip Islam moderat, baik melalui peralawanan fisik maupun ideologi. Di Indonesia, perlawanan ideologi lebih dikedepankan oleh syaikh-syaikh Tarekat Naqshabandīyah dengan cara mendekati para elit politik dan penguasa. Dengan tujuan, mereka bisa memberikan massa. Karena tarekat yang memiliki ajaran rasa cinta pada negara (nasionalisme) adalah tarekat yang menganut ajaran syariah, karena cinta negara adalah bentuk wujud keimanan yang berlandas pada syariah. Dengan demikian, model tarekat modern sebenarnya mengimplementa-sikan nilai-nilai sufi ekletis yang menggabungkan pengakuan kehidupan duniawi, ritual amaliah spiritual dan berlandaskan syariah. ${ }^{51}$

Di dunia modern, khususnya di Indonesia, ajaran sufi bersifat eklektisisme tercermin dari penghayatan batini (esoterisme) yang menginkan hidup aktif pada masalah-masalah sosial kemasyarakatan dengan tanpa melepaskan aktivitas spiritual untuk mencapai ma'rifat Allah. Ajaran sufi eklektisisme muncul sebagai upaya membangkitkan kembali semangat keberagamaan umat Islam untuk menanamkan sikap positif pada dunia dari hentakan kaum tasawuf klasik. ${ }^{52}$ Beberapa corak tarekat dengan prinsip eklektisisme tertuang pada

${ }^{50}$ Ja'far, “Tarekat dan Gerakan Sosial Keagamaan Shaykh Hasan Maksum”, Teosofi: Jurnal Tasawnf dan Pemikiran Islam 5, no. 2 (2015), 143-145.

51 Muhammad Faiz, "Khazanah Tasawuf Nusantara: Tarekat Naqsyabandiyyah Khalidiyyah di Malaysia”, 'Anil Islam 9, no. 2 (2016), 187-188.

52 Zakaria Stapa, Memasyaratkean Kefahaman dan Amalan Ilmu Tasaawuf di Malaysia Masa Kini (Selangor: Universiti Kebangsaan Malaysia, 2015), 60. 
coraknya yang lebih "revolusioner", baik pada esensi doktrin maupun kelembagaannya. Dari aspek doktrinal, memiliki corak tidak sepakat dengan penghormatan kepada wali secara berlebihan, menjauhkan tasawuf dari asketisme dan memiiki titik penekanan pada aktifisme praktis. Maka jelas, bahwa tujuan amalan zikir mengarah pada penyatuan dengan Nabi Muhammad Saw, bukan pada Tuhan, karena landasan syariah yang menyertainya. ${ }^{53}$

Dari aspek kelembagaan, tarekat sufi eklektisisme memiliki ciri teroganisir dari cabang sampai ke pusat, sehingga ruh ajaran sufi bisa tersampaikan secara generatif, sanadnya bersambung sampai ke Rasulullah. Sehingga mereka tidak mudah terpengaruh ataupun terpecah-belah. ${ }^{54}$ Sebagai bentuk mengakui kehidupa dunia, prinsip eklektisisme menggunakan bentuk organisasi sosial dengan cara melibatkan diri pada kegiatan-kegiatan politik. Sebab ranah-ranah politik, kekuasaan, ekonomi, budaya, sosial adalah bentuk kesadaran bahwa manusia berada pada kehidupan duniawi yang tidak dapat dipungkiri, seperti tanggung-jawabnya pada keluarga, pada negara, masyarakat dan organisasi adalah bentuk pengakuan kehidupan duniawi. Ajaran sufi eklektisisme tidak bisa menafikan, karena hal demikian juga bagian dari kewajiban syariah.

Corak sufi eklektisisme telah memberikan pondasi ajaran sufi yang kuat bagi munculnya gerakan-gerakan berbasis agama setelahnya, baik bersifat samar maupun radikal. Seperti aliran-aliran keagamaan baik bercorak sufistik maupun bukan, yang membawa hawa penetrasi agama Islam dan sekularistik telah mampu dihempas oleh tarekattarekat sufi bernafaskan eklektisisme sehingga menjadi tameng ajaran sufi yang tangguh. Corak eklektisisme menekankan pada tiga wilayah penting; menyadari kehidupan duniawi, ritual spiritual dan berlandas pada syariah. Di saat bersamaan, Indonesia merupakan aliran agama dengan penganut Sunnī mayoritas. ${ }^{55}$ Dari akar sejarahnya, Sunnī adalah kekuatan pertama yang mendukung paham sufi eklektisisme, sebagai ajaran sufi yang mashur abad kedua Hijriyah hingga sekarang.

53 Mohd. Rumaizuddin Ghazali, "Pemikiran Tasawuf dan Kehidupan Kerohanian Abu Hasan Ali al-Nadwi (1914-1999): Satu Analisis", Jurnal al-Manhal 12, no. 2 (2015), 88-89.

54 J. Spencer Trimingham, The Sufi Order in Islam dalam Agus Riyadi, "Tarekat sebagai Organisasi Tasawuf (Melacak Peran Tarekat dalam Perkembangan Dakwah Islamiyah)", Jurnal at-Taqaddum 6, no. 2 (2014), 359-362.

55 Khusnul Khotimah, "Interkoneksitas dalam Ajaran Sosial Tasawuf Sunni dan Falsafi”, Komunika: Jurnal Dakwah dan Komunikasi 9, no. 1 (2015), 10-12. 
Sehingga antara ajaran Sunnī yang mengusung konsep moderasi agama dengan ajaran eklektisisme bertemu pada payung ideologi yang sama.

Dengan demikian, konsep aliran sufisme bercorak eklektisisme memiliki tingkat relevansi sangat kuat dengan corak keagamaan di Indonesia. Tidak ayal jika aliran sufi seperti Naqshabandīyah, Qādirīyah, 'Idrīsīyah, 'Alawīyah dan lain-lain eksis sampai sekarang. Aliran tarekat ini memang berbeda secara amalan dan doktrin, namun perbedaan tersebut bukan pada ranah prinsipil. Dalam artian, tarakattarekat besar tersebut menggunakan syariah sebagai landasan, di samping amalan-amalan zikir untuk mencapai ma'rifat Allah dan tidak menafikan kehidupan duniawi. Relevansi antara Sunnī dengan model gerakan sufi eklektis yang mengusung moderasi sufi adalah corak prinsip bersufi yang ideal, dari dulu hingga era kontemporer.

\section{Catatan Akhir}

Dari pembahasan dan diskusi diatas, dapat disimpulkan dua hal penting yaitu: pertama, corak ajaran sufi yang menganut model eklektisisme memiliki akar sejarah cemerlang sebagai penyeimbang antara yang profan dan sekuler. Corak sufi eklektisisme memuat tiga prinsip dasar ajaran sufi yaitu menyadari kehidupan duniawi sebagai realitas tak terbantahkan, ritual amaliah spiritual seperti zikir serta berpangku pada syariah. Dalam artian, pendekatan sufi eklektisisme menekankan pada konsep moderasi sufi, integralitas antara ajaran tasawuf dengan ritual syariah. Kedua, ajaran sufi dengan corak eklektisisme memiliki tingkat relevansi yang kuat dengan corak beragama di Indonesia. Dari akar sejarah perkembangan corak sufi eklektisisme didukung oleh doktrin ortodoks (Sunni), tokoh-tokoh seperti Junayd al-Baghdādī, al-Ghazālī dan tokoh sufi sealiran adalah tokoh yang menyandarkan pemikiran sufi kepada al-Qur'ān dan Hadīth serta pedapat para ulama. Artinya, bukan hanya secara doktrinal ataupun ajaran, dari aspek kelembagaan juga memiliki visi yang sama. Dengan demikian, corak eklektisisme seimbang dan relevan dengan corak keagamaan Sunnī di Indonesia.

\section{Daftar Rujukan}

Abidin, Munirul. "Pandangan Neo Sufisme Nurcholis Madjid (Studi tentang Dialektika antara Tasawuf Klasik dan Tasawuf Modern di Indonesia)", Ulul Albab 9, no. 1, 2008. 
al-Haramain, Elmansyah. Paradigma Peradaban Islam dalam Tasawuf: Sebuah Pemaparan Awal. Bandung: Mizan, 2014.

al-Husain Ahmad bin Abdul Aziz dan Numsuk, Abdullah Mustofa. Kesesatan Sufi: Tasawuf, Ajaran Budha. Jakarta: Pustaka as-Sunnah, 2001.

al-Kumayi, Sulaiman. "Gerakan Pembaruan Tasawuf di Indonesia", Jurnal Theologia 24, no. 2, 2013.

Alba. Tasawuf dan Tarekat. Bandung: PT Remaja Rosdakarya, 2012.

Algar, Hamid. "The Naqshbandi Order: A Preliminary Survey of its History and Significance" dalam M. Arif Khoiruddin, "Peran Tasawuf dalam Kehidupan Masyarakat Modern", Tribakti: Jurnal Pemikiran Keislaman 27, no. 1, 2016.

Ali, Yunasril. "Dualisme: Pemikiran Sufistik Ibn Taymiyyah", Kanz Philosophia 4, no. 2, 2014.

Arberry, A.J. "Sufism: an Account of the Mystics of Islam" dalam Aceng Kosasih, "The Tradition for Spiritual Learning (Tariqat) Through a Sequence of Holy Phrases (Tijaniyah): The Case of Darussalam Boarding School”, Asian Social Science 11, no. 2, 2015.

As'ad, Mahrus. "Pengaruh Nesufisme terhadap Perkembangan Tasawuf dan Tarekat Baru", Miqat XXXVI, no. 1, 2012.

Azwar, Alfi Julizun. "Tasawuf dan al-Qur'ān Tinjauan Dunia Ilmu Pengetahuan dan Praktek Kultural-Religius Ummat", Intizar 19, no. 2, 2013.

Basri, Thahirah Binti Hassan., Badaruddin, Faudzinaim bin., dan Mohamad, Abdul Manam bin. "Konsep Zikir Darajah dalam Disiplin Ilmu Tarekat", Jurnal Islam dan Masyarakat Kontermporer 8, no. 2, 2014.

Bohart, Arthur C. dan Greening, Thomas. "Comment: Humanistic Psychology and Positivve Psychology", Journal American Psychologist 56, no. 1, 2001.

Bruinessen, Martin van. Kitab Kuning, Pesantren dan Tarekat. Yogyakarta: Gading Publishing, 2015.

----. Tarekat Naqshabandīyah di Indonesia. Bandung: Mizan, 1998.

Faiz, Muhammad. "Khazanah Tasawuf Nusantara: Tarekat Naqsyabandiyyah Khalidiyyah di Malaysia”, 'Anil Islam 9, no. 2, 2016. 
Farida, Meutia. "Perkembangan Pemikiran Tasawuf dan Implementasinya di Era Modern", Jurnal Substantia 12, no. 1, 2011.

Ghazali, Mohd. Rumaizuddin. "Pemikiran Tasawuf dan Kehidupan Kerohanian Abu Hasan Ali al-Nadwi (1914-1999): Satu Analisis", Jurnal al-Manbal 12, no. 2, 2015.

Haryanto, Joko Tri. "Perkembangan Dakwah Sufistik Perspektif Tasawuf Kontemporer", Addin 8, no. 2, 2014.

Hidayati, Tri Wahyu. "Perwujudan Sikap Zuhud dalam Kehidupan", Millati: Journal of Islamic Studies and Humanties 1, no. 2, 2016.

Hoopwood, Derek. "A Pattern of Revival Movements in Islam?" dalam Armyn Hasibuan, "Neo-Sufisme, Ragam dan Perkembangannya (Mampukah Membangun Konstruksi Baru)", Hikmah 7, no. 2, 2013.

Ja'far, "Tarekat dan Gerakan Sosial Keagamaan Shaykh Hasan Maksum", Teosofi: Jurnal Tasawnf dan Pemikiran Islam 5, no. 2, 2015.

Khamami, Akhmad Rizqon. "Tasawuf Tanpa Tarekat: Pengalaman Turki dan Indonesia", Teosofi: Jurnal Tasawnf dan Pemikiran Islam 6, no. 1, 2016.

Khotimah, Khusnul. "Interkoneksitas dalam Ajaran Sosial Tasawuf Sunni dan Falsafi", Komunika: Jurnal Dakwah dan Komunikasi 9, no. 1, 2015.

Khozin. Sufi tanpa Tarekat: Praksis Keberagamaan Muslim Puritan. Malang: Madani, 2013.

Laan, R.J.I. Ter. "Sanusi Revivalism as Part of the Fundamentalist Tradition in Islam," dalam Nicola A. Ziaderh, Sanusiab: a Study of a Revivalist Movement in Islam. Leiden: E.J. Brill, 1983.

Lapidus, Ira M. History of Islamic Societies. Cambridge: Cambridge University Press, 1993.

Madjid, Nurcholish. Islam Agama Peradaban: Membangun Makna dan Relevansi Doktrin Islam dalam Sejarah. Jakarta: Paramadina, 2000.

-----. Islam Doktrin dan Peradaban: Sebuah Telaah Kritis tentang Maslahab Keimanan, Kemanusiaan dan Kemodernan. Jakarta: Yayasan Wakaf Paramadina, 1992.

Mas'ud, Ali. "Analisis dan Mapping Syariah Versus Tasawuf melalui Pendekatan Historis", Episteme 8, no. 1, 2013. 
Mohammad Fahmi Abdul Hamid, Ishak Hj Suliaman, dan Mohd Farhan Md Ariffin, "The Concept of Zuhud Based on Fiqh Hadith”, Jurnal Intelek 11, no. 1, 2016.

Mulyadi, Achmad. "Budaya Egalitarianisme Perempuan Madura dalam Tarekat Naqshabandīyah", Karsa: Jurnal Sosial dan Budaya Keislaman 23, no. 1, 2015.

Nasution, Harun. Filsafat dan Mistisisme dalam Islam. Jakarta: Bulan Bintang, 1973.

Nicholson, Reynold A. "Sufism" dalam James Hastings, Encyclopaedia of Religion and Etics. London: Charles Scribe's, t.th.

----. The Mystics of Islam. London: Kegan Paul, 1966.

Noupal, Mohammad. "Tarekat Naqsabandiyah di Indonesia Abad 19 dari Ortodoksi ke Politisasi”, Intizar 22, no. 2, 2016.

Nursyam. Perkembangan Kaum Tarekat. Surabaya: LEPKISS, 2004.

O'Fahey, R.S. Enigmatic Saint: Abmad Ibn Idrisi and the Idrisi Tradition. London: Hurst and Company, 1990.

Rahman, Fazlur. Islam. Chicago: the University of Chicago Press, 1979.

Rijal, Syamsul. "Kritik Ibnu Taimiyah terhadap Tarekat", Jurnal Penelitian dan Pemikiran Keislaman 2, no. 1, 2015.

Riyadi, Agus. "Tarekat sebagai Organisasi Tasawuf (Melacak Peran Tarekat dalam Perkembangan Dakwah Islamiyah)", Jurnal atTaqaddum 6, no. 2, 2014.

Riza, Kemal A. "Ascetism in Islam and Christianity: with Reference to Abu Hamid al-Ghazali and Francis of Assisi", Toesofia: Indonesian Journal of Islamic Mysticism 1, no. 1, 2012.

Said, Muh. "Metodologi Penafsiran Sufistik: Perspektif al-Ghazali", Jurnal Diskursis Islam 2, no. 1, 2014.

Sajari, Dimyati. “Keotentikan Ajaran Tasawuf”, Dialog 38, no. 2, 2015.

Salimi, Mahfud. "Reformasi Tasawuf al-Ghazali dan Relevansinya dengan Pendidian Islam", Az-Zikr: Jurnal Pendidikan Agama Islam 1, no. 1, 2016.

Schimmel, Anemearie. Mystical Dimenssions of Islam dalam Abdelilah Bousria, Sufism and Politics in Morocco: Activism and Dissent. New York: Routledge, 2015.

Shihab, Alwi. Islam Sufistik: Islam Pertama dan Pengarubnya Hingga Kini di Indonesia. Bandung: Mizan, 2001. 
Shodiq, Muhammad. "Eksistensi dan Gerakan Dakwah Tarekat Șiddîqîyah di Tengah Masyarakat Urban Surabaya", Teosofi: Jurnal Tasawuf dan Pemikiran Islam 5, no. 2, 2015.

Siregar, H. A. Rivay. Tasawnf dari Sufisme Klasike ke Neo-sufisme, Cet. II. Jakarta: Raja Grafindo Persada, 2002.

Solihin, M. dan Anwar, Rosihon. Ilmu Tasawuf. Bandung: Pustaka Setia, 2011.

Stapa, Zakaria. Memasyaratkan Kefahaman dan Amalan Ilmu Tasaawuf di Malaysia Masa Kini. Selangor: Universiti Kebangsaan Malaysia, 2015.

Ubaidillah. "Fitrah dan Potensi Insani daam Ilmu Tasawuf (Perspektif erapi Psikologis dan Bimbingan Konseling)", Jurnal Konseling Religi: Jurnal Bimbingan Konseling Islam 1, no. 1, 2010.

Usman. "Urban Sufisme: Jalan Menemukan Kembali Humaintas yang Hilang Akibat Modernitas", Jurnal Tasawnf 1, no. 1, 2012. 